\title{
Piper Nigrum Protects Against Fe (II) Mediated Lipid Peroxidation in Phopholipids Liposomes: Analytical and Biochemical Analysis
}

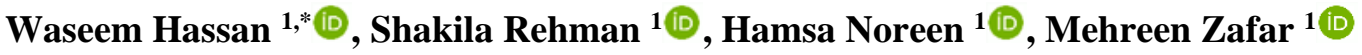 \\ 1 Institute of Chemical Sciences, University of Peshawar, Peshawar 25120, Khyber Pakhtunkhwa, Pakistan \\ * Correspondence: waseem_anw@yahoo.com;
}

Scopus Author ID 25651506900

Received: 10.02.2021; Revised: 15.04.2021; Accepted: 20.04.2021; Published: 8.05.2021

\begin{abstract}
Phospholipids liposomes were employed to access the extent of Iron [Fe(II)] induced lipid peroxidation. Our data indicate that $\mathrm{Fe}$ (II) caused a significant increase in malondialdehyde (MDA) formation, a lipid peroxidation product. Ethanolic extract of Piper Nigrum $(P N)$ significantly inhibited lipid peroxidation at the highest tested concentrations. The plant with three different extracts (aqueous, ethanolic, and ethyl acetate)was tested for its nutritional value, and a higher amount of carbohydrates (42.66\%), fibers $(20.96 \%)$, and proteins $(14.38 \%)$ were recorded. The mineral content evaluated by atomic absorption spectrophotometry (AAS) showed Ca (30.400 mg/L), Mg (10.475 mg/L), and Mn $(2.391 \mathrm{mg} / \mathrm{L})$ in higher concentrations. Quantitative gas chromatographic analysis coupled with a mass spectrometer (GCMS) was used to explore the characteristic biochemical compounds, which confirmed the presence of twenty-four (24) active constituents. D-Limonene (18.59\%) was present in higher concentrations, followed by beta-pinene (17.98\%), alpha-pinene (12.85\%), and caryophyllene (9.91\%). Plant extracts and essential oil were further tested against six (6) gram-negative, three (3) gram-positive, and a fungal strain by disc diffusion method. The presence of active compounds in essential oil and crude extracts may be responsible for observed pharmacological efficacies of PN and can be considered as a nutraceutical for the treatment of oxidative stress-related and pathogenic diseases.
\end{abstract}

Keywords: Piper Nigrum; phospholipids liposome; lipid peroxidation; metallic screening; GCMS.

(C) 2021 by the authors. This article is an open-access article distributed under the terms and conditions of the Creative Commons Attribution (CC BY) license (https://creativecommons.org/licenses/by/4.0/).

\section{Introduction}

The uses of natural products obtained from plant origin have been known for thousands of years because of their safe mode of action and negligible adverse side effects as compared with synthetic drugs. Modern scientific research has proved the presence of essential bioactive components in medicinal plants. These chemical bio-active constituents of plants are responsible for their therapeutic activity against many diseases and produce a definite physiological action on the human body[1]. Many plant-derived molecules account for excellent activities in the prevention of diseases [2]. Literature has demonstrated that medicinal plants and spices are extensively used in agricultural production and pharmaceutical industries. Special attention has been paid to the properties of spices in recent years, as they are believed to be known for their medicinal and preservative value [3].

The pepper family (Piperacae) shows great efficacy and potential in various pathological models [4]. PN (black pepper) belongs to Piperacae, is a monoecious or decorous vine cultivated for its fruit in South East Asia and tropical regions and usually used as a spice 
and seasoning additive. Certain chemical constituents in the essential oil of $P N$ impart it characteristic pepper aroma and flavor. The predominant bioactive constituents of $P N$ are piperine, (-)-kusunokinin, piperolein B, piperlonguminine, piperamide etc.[5]. Literature has reported anti-carcinogenic [6], antimicrobial [7], antioxidant [8], larvicidal [9] , anti-glycation [10] properties of the stated plant. The essential oils obtained from $P N$ acts as protective agents against oxidative stress [11]. The herb and seeds have been used to treat asthma, chronic indigestion, colon toxins, obesity, sinus, congestion, and fever [12], intermittent fever, cold extremities, colic, gastric ailments, and diarrhea [13]. Piperine, an alkaloid of black pepper, is present in fairly large amounts $(3-8 \mathrm{gm} / 100 \mathrm{gm})$ and mainly responsible for its pungent character [14]. Similarly, absorption of certain vitamins, selenium, and $\beta$-carotene is efficiently increased by piperine. $P N$ has also been reported to possess anti-inflammatory, anti-malarial, antileukemia, and potent antitussive properties [15, 16] [17].

However, there is still a scarcity of in vitro data in the literature about the antioxidant activity of $P N$ in a pure chemical model system and antimicrobial efficacies of their fruits. Lipid peroxidation is usually measured in rat's tissue homogenate, but there are various artifacts associated with the use of pure tissue homogenate, i.e., interference of protein oxidation and certain DNA damage products. For this purpose, a rich lipid source i.e., phospholipids extract from egg yolk, was used in the present study. We tried to explore whether the $P N$ fruit extract could protect against iron $[\mathrm{Fe}(\mathrm{II})]$ induced lipid peroxidation. The antimicrobial activity of ethyl acetate, ethanolic, and water extract of PN fruit against fungal, gram-positive, and gram-negative bacterial strains was also evaluated. Since $P N$ has been traditionally used in pharmaceutical preparation as raw material, and its fruit is utilized as food; therefore potent therapeutic agents may be developed by biological investigation of this interesting plant. A detailed systematic approach towards the presence of various active phytoconstituents and the approximate chemical composition of $P N$, was also reported. For the identification of various active components of $P N$, its essential oil was characterized by GCMS analysis. The elemental contents were analyzed by atomic absorption spectrophotometer.

\section{Materials and Methods}

\subsection{Chemicals.}

Ethyl alcohol, ethyl acetate, hexane, dimethyl sulfoxide (DMSO), chloroform, $\mathrm{H}_{2} \mathrm{SO}_{4}$, $\mathrm{NaOH}, \mathrm{FeCl}_{3}, \mathrm{CuSO}_{4}, \mathrm{~K}_{2} \mathrm{SO}_{4}$, and other reagents used were of analytical grade and obtained from a standard supplier and further verified by the Pakistan Council of Scientific and Industrial Research (PCSIR) laboratories complex Peshawar, Pakistan.

\subsection{Approximate analysis.}

Standard methods, according to the Association of Official Analytical Chemists [18], were used for the determination of ash, moisture, crude fat, crude fiber, and carbohydrate, while proteins were determined by Kjeldahl method [19].

\subsection{Phytochemical screening.}

A powdered sample (200 gm) of $P N$ was taken in three separate conical flasks and extracted with ethyl acetate, ethanol, and water, respectively. The flasks were kept on a water bath for 5-6 hours and shaken at intervals. The solution was filtered, and the filtrate was 
concentrated to dryness under reduced pressure at $90^{\circ} \mathrm{C}$ on a rotary vacuum evaporator. The respective extracts were transferred to vials and used for further investigation. Standard procedures for the identification of secondary metabolites were used [20, 21].

\subsection{Mineral analysis.}

The quantitative estimation of macro $(\mathrm{Ca}, \mathrm{Mg})$ and micro minerals $(\mathrm{Cu}, \mathrm{Fe}, \mathrm{Zn}, \mathrm{Cr}, \mathrm{Ni}$, $\mathrm{Mn}$ ) was analyzed by atomic absorption spectrophotometry (AAS) by the method of [22].

\subsection{Phospholipids extraction and TBARS production.}

Production of TBARS from phospholipids was determined using the method of [23] with certain modifications.

\subsection{Antimicrobial activities.}

Antimicrobial activities were investigated by using the standard procedure of [24]. Briefly, 0.2-0.5g of the three extracts (ethyl acetate, ethanol, water) were dissolved separately in weight dependant calculated DMSO concentration; hexane was used for dissolving essential oil. The extracts were then used for the antimicrobial assay.

\subsubsection{Test microorganisms.}

The pathogens tested in our study were: Agrobacterium tumefaciens, Erwinia carotovora, Eschericia coli, Klebsiella pneumoniae, Salmonellatyphi, Pneumococcusauroginosa, Bacillus atrophoeus, Bacillus subtillus, Staphylococcus aureus, and Candida albicans (fungus). All the strains were obtained from PCSIR laboratories complex Peshawar.

DMSO and hexane used for making stock solutions were used as a negative control, while standard antibiotics such as ciprofloxacin, azithromycin, and clotrimazole were applied as positive controls or reference standards against gram-negative, gram-positive bacterial, and fungal strain, respectively.

\subsection{GC-MS analysis.}

GC-MS analysis was performed following the standard method used by [25] with certain changes. The essential oil was extracted by using Dean Stark's apparatus. About $715 \mathrm{~g}$ of a coarsely powdered sample of $P N$ was taken in the distillation flask, filled $2 / 3^{\text {rd }}$ with distilled $\mathrm{H}_{2} \mathrm{O}$, placed on a water bath, and heated. The volatile components were evaporated with water vapors and condensed back via the condenser attached to the distillation flask. The essential oil layer, having low density, was accumulated over water, which was subsequently separated and dried by adding anhydrous sodium sulfate $\left(\mathrm{Na}_{2} \mathrm{SO}_{4}\right)$. The solution was then filtered and employed for GC-MS analysis.

The data regarding percentage composition, peak area, and retention time was obtained by comparing the obtained mass spectrum to the standard mass spectra from the National Institute Standard and Technology (NIST 05) library. 


\section{Results and Discussion}

The extractive yields with ethyl acetate, ethanol, and distilled water are found to be $(4.45 \%),(4.25 \%)$ and $(2.15 \%)$ respectively, and presented in Table 1 . The approximate analysis revealed carbohydrates $(42.66 \%)$ in the highest amount, followed by crude fiber (20.96\%) and proteins (14.38\%), while crude fat, ash, and moisture values were recorded as $(6.39 \%),(4.18 \%)$ and $(11.43 \%)$ respectively as shown in Table 2. Further analysis of ash for macro and micronutrient content, using AAS showed that $\mathrm{Ca}(30.400 \mathrm{mg} / \mathrm{L}), \mathrm{Mg}(10.475 \mathrm{mg} / \mathrm{L})$ and $\mathrm{Mn}(2.391 \mathrm{mg} / \mathrm{L})$ were present in highest concentration followed by $\mathrm{Zn}(0.637 \mathrm{mg} / \mathrm{L}), \mathrm{Fe}$ $(0.620 \mathrm{mg} / \mathrm{L}), \mathrm{Ni}(0.261 \mathrm{mg} / \mathrm{L}), \mathrm{Cr}(0.140 \mathrm{mg} / \mathrm{L})$ and $\mathrm{Cu}(0.152 \mathrm{mg} / \mathrm{L})($ Table 3$)$. Preliminary phytochemical screening of $P N$ was carried out using different solvent extractions. (Table 4). Our data indicated the presence of alkaloids, terpenoids, steroids, glycosides, and flavonoids in all three (ethyl acetate, ethanol, and water) solvent extracts, while a negative result for tannins was reported with ethyl acetate and alcohol extracts. One-way ANOVA of phospholipids TBARS production revealed a significant main effect of Fe(II). Fig.1 indicated that $\mathrm{Fe}(\mathrm{II})$ caused a significant increase in TBARS production, and $P N$ inhibited lipid peroxidation at the highest tested concentrations. Antimicrobial activities of the extracts and essential oil on test microorganisms are presented in Table 6. Our results revealed that essential oil exhibited considerable inhibitory effects against all the tested organisms. The maximum zones of inhibition (ZI) for essential oil at $2 \mathrm{mg} / \mathrm{mL}$ concentration were recorded against A.tumefaciens $(25 \mathrm{~mm})$, followed by C.albicans $(21 \mathrm{~mm})$, E.carotovora $(16 \mathrm{~mm})$ and with equal activity against E.coli $(14 \mathrm{~mm})$ and S.typhi $(14 \mathrm{~mm})$. Aqueous extract displayed maximum zone of inhibition against S.typhi $(15 \mathrm{~mm})$, followed by B.atrophoeus $(14 \mathrm{~mm})$, K.pneumoniae $(13 \mathrm{~mm})$, and C.albicans $(12 \mathrm{~mm})$. Ethanolic extract was most effective against B.atrophoeus $(\mathrm{ZI}=13 \mathrm{~mm})$ and S.Aureus $(\mathrm{ZI}=12 \mathrm{~mm})$. No antibacterial activity (for ethanolic extract) was observed at both tested concentrations $(1 \mathrm{mg} / \mathrm{mL} \& 2 \mathrm{mg} / \mathrm{mL})$ against E.carotovora, E.coli, $K$ pneumoniae, S.typhi and $B$. subtilis. Ethyl acetate extract showed maximum activity against $B$. subtilis and B. atrophoeus each (ZI=16mm). While, an inhibition zone of $13 \mathrm{~mm}$ was recorded for E.carotovora, K.pneumoniae, P. aeruginosa, and C.albicans. GCMS analysis of essential oil showed 24 constituents in the local variety of $P N$. Furthermore, essential oil was rich in Dlimonene $(18.59 \%)$, beta-pinene $(17.98 \%)$, alpha-pinene $(12.85 \%)$, caryophyllene $(9.91 \%)$, 3carene $(8.51 \%)$ and tricyclo[2.2.1.0(2,6)] heptane,1,3,3-trimethyl $(8.51 \%)$ while o-cymene, $\mathrm{p}$ cymene-3-ol ,beta-myrcene, alpha-caryophyllene, bicyclo [3.1.0]hexane,4-methylene-1-(1methylethyl), gamma-terpinen and copaene comprise approximately $20 \%$ of the essential oil as shown in Table 5.

Table 1. Percentage (\%) yield of extracts of Piper Nigrum.

\begin{tabular}{c|c|c|c} 
Ethyl acetate (\%) & Ethyl alcohol (\%) & Water (\%) & Essential oil (\%) \\
\hline 4.45 & 4.25 & 2.15 & 1.25
\end{tabular}

Table 2. Percentage yields of the chemical composition of Piper nigrum.

\begin{tabular}{|c|c|c|c|c|c|c|}
\hline $\begin{array}{c}\text { Ash value } \\
(\%)\end{array}$ & $\begin{array}{c}\text { Moisture } \\
\text { Content }(\%) \\
\end{array}$ & $\begin{array}{c}\text { Essential Oil } \\
(\%)\end{array}$ & Crude fats (\%) & $\begin{array}{c}\text { Crude Fibers } \\
(\%)\end{array}$ & Carbohydrate (\%) & $\begin{array}{c}\begin{array}{c}\text { Protein } \\
(\%)\end{array} \\
\end{array}$ \\
\hline 4.18 & 11.43 & 1.25 & 6.39 & 20.96 & 42.66 & 14.38 \\
\hline
\end{tabular}

Table 3. Metallic screening of Piper nigrum.

\begin{tabular}{c|l|c|c|c|c}
\multicolumn{1}{l|}{ S.no } & Analyte & Wavelength $(\mathbf{n m})$ & Mean $(\mathbf{m g} / \mathbf{L})$ & Std. Dev & \% RSD \\
\hline 1. & Manganese & 279.5 & 2.391 & 0.0439 & 1.83 \\
\hline 2. & Chromium & 357.9 & 0.140 & 0.0081 & 5.77 \\
\hline 3. & Iron & 248.3 & 0.620 & 0.0182 & 2.93
\end{tabular}




\begin{tabular}{c|l|c|c|c|c}
\multicolumn{1}{l|}{ S.no } & Analyte & Wavelength $(\mathbf{n m})$ & Mean $(\mathbf{m g} / \mathbf{L})$ & Std. Dev & \% RSD \\
\hline 4. & Nickel & 232.0 & 0.261 & 0.0352 & 13.49 \\
\hline 5. & Zinc & 213.9 & 0.637 & 0.0099 & 1.55 \\
\hline 6 & Copper & 324.8 & 0.152 & 0.0106 & 7.00 \\
\hline 7. & Magnesium & 285.4 & 10.475 & 0.0004 & 0.10 \\
\hline 8. & Calcium & 422.7 & 30.400 & 0.0643 & 5.29
\end{tabular}

Std.Dev $=$ Standard deviation $\mathrm{RSD}=$ Relative standard deviation

Table. 4. Phytochemical screening results of Piper Nigrum.

\begin{tabular}{|c|c|c|c|}
\hline S.No & Phytochemical constituents & Solvent & Result \\
\hline \multirow[t]{3}{*}{1} & \multirow[t]{3}{*}{ Alkaloids } & E.A & + \\
\hline & & E.OH & + \\
\hline & & $\mathrm{H}_{2} \mathrm{O}$ & + \\
\hline \multirow[t]{3}{*}{2} & \multirow[t]{3}{*}{ Glycosides } & E.A & + \\
\hline & & E.OH & + \\
\hline & & $\mathrm{H}_{2} \mathrm{O}$ & + \\
\hline \multirow[t]{3}{*}{3} & \multirow[t]{3}{*}{ Terpenoids } & E.A & + \\
\hline & & E.OH & +++ \\
\hline & & $\mathrm{H}_{2} \mathrm{O}$ & +++ \\
\hline \multirow[t]{3}{*}{4} & \multirow[t]{3}{*}{ Steroids } & E.A & + \\
\hline & & E.OH & ++ \\
\hline & & $\mathrm{H}_{2} \mathrm{O}$ & ++ \\
\hline \multirow[t]{3}{*}{5} & \multirow[t]{3}{*}{ Tannins } & E.A & $\ldots$ \\
\hline & & E.OH & _- \\
\hline & & $\mathrm{H}_{2} \mathrm{O}$ & + \\
\hline \multirow[t]{3}{*}{6} & \multirow[t]{3}{*}{ Flavonoids } & E.A & + \\
\hline & & E.OH & + \\
\hline & & $\mathrm{H}_{2} \mathrm{O}$ & + \\
\hline
\end{tabular}

$(+++)$ =high amount, $(++)=$ moderate amount, $(+)=$ low amount

Table 5. GCMS values of volatile oil components of Piper nigrum.

\begin{tabular}{|c|c|c|c|c|c|}
\hline S. no & Name & Structure & R.Time & Area & Conc. $(\%)$ \\
\hline 1 & Alpha-phallendrene & & 9.620 & 15058 & 0.46 \\
\hline 2 & Alpha-pinene & & 9.960 & 422409 & 12.85 \\
\hline 3 & Camphene & & 10.791 & 7359 & 0.22 \\
\hline 4 & $\begin{array}{l}\text { Bicyclo[3.1.0]hexane, } \\
\text { 4-methylene-1-(1-methyl) }\end{array}$ & & 12.145 & 64311 & 1.96 \\
\hline 5 & Beta.-pinene & & 12.372 & 591187 & 17.98 \\
\hline 6 & Beta.-myrcene & & 13.250 & 114975 & 3.50 \\
\hline 7 & $\begin{array}{l}\text { Tricyclo[2.2.1.0(2,6)] } \\
\text { Heptane,1,3,3-trimethyl }\end{array}$ & & 14.152 & 279658 & 8.51 \\
\hline 8 & 3-carene & & 14.152 & 279658 & 8.51 \\
\hline
\end{tabular}




\begin{tabular}{|c|c|c|c|c|c|}
\hline S. no & Name & Structure & R.Time & Area & Conc. $(\%)$ \\
\hline 9 & Alpha.-terpinen & & 14.789 & 3552 & 0.11 \\
\hline 10 & O-cymene & & 15.306 & 177513 & 5.40 \\
\hline 11 & D-limonene & & 15.616 & 611210 & 18.59 \\
\hline 12 & Gamma.-terpinen & & 17.458 & 55108 & 1.68 \\
\hline 13 & P-mentha-1,4(8)-diene & & 19.211 & 24398 & 0.74 \\
\hline 14 & Beta.-linalool & & 20.454 & 10267 & 0.31 \\
\hline 15 & P-cymene-3-ol & & 32.515 & 144677 & 4.40 \\
\hline 16 & Alpha.-cubebene & & 34.989 & 2798 & 0.09 \\
\hline 17 & Copaene & & 36.333 & 38097 & 1.16 \\
\hline 18 & $\begin{array}{l}\text { Cyclohexane-2,4- } \\
\text { Diisopropenyl-1 }\end{array}$ & & 37.056 & 11206 & 0.34 \\
\hline
\end{tabular}




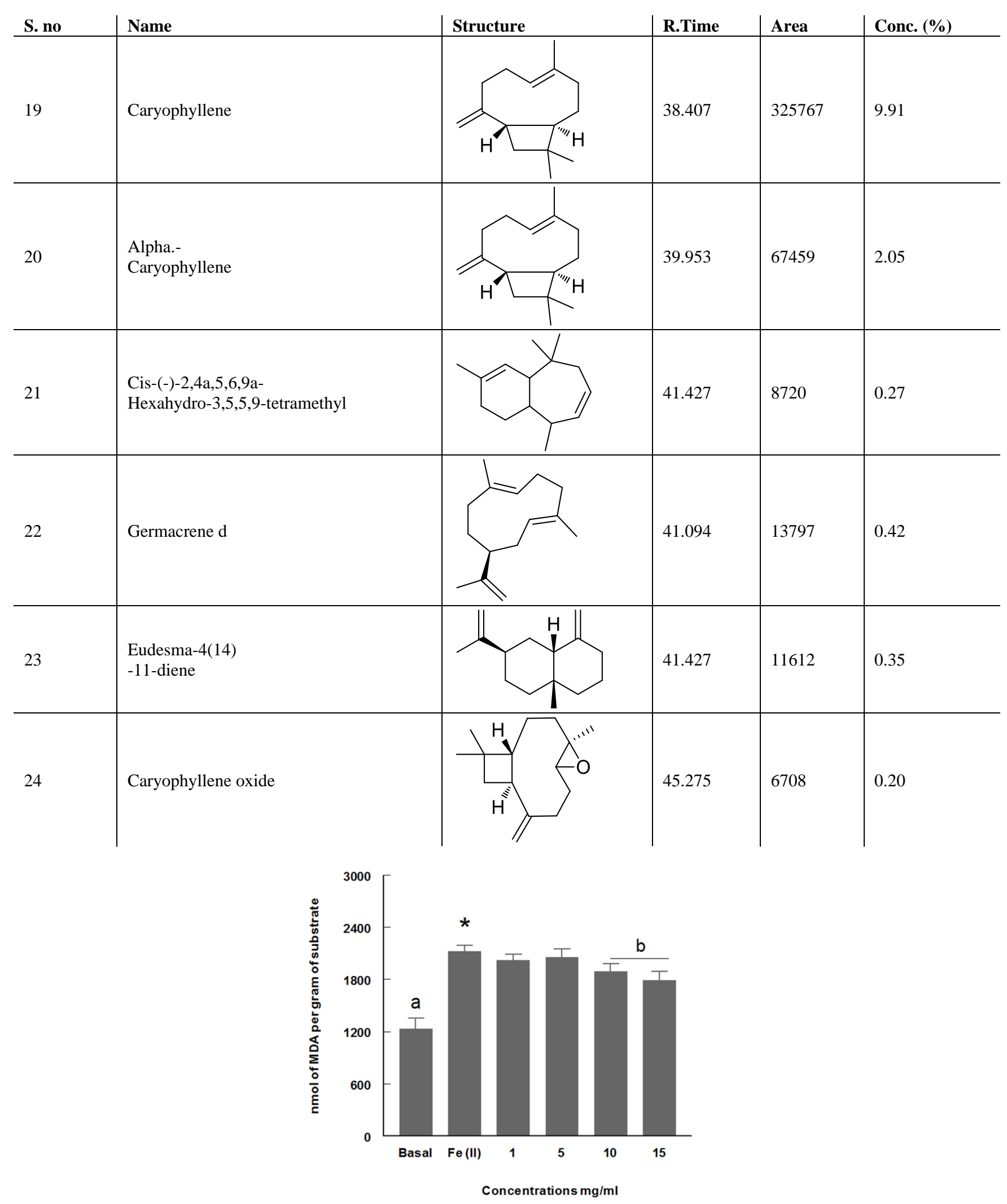

Figure 1. Effect of Piper nigrum on Fe(II)-induced $(20 \mu \mathrm{M})$ TBARS production in phospholipids extract from egg yolk. The values are expressed as nmol of MDA per gram of substrate. Data are expressed as means \pm S.E.M. $(n=5-7)$. Asteric/s shows main effect of $\mathrm{Fe}(\mathrm{II})$ at $\mathrm{p}<0.05$ while different letter denotes significant difference from control group. 
Table 6. Antimicrobial activities of Piper nigrum Zone of inhibition in mm

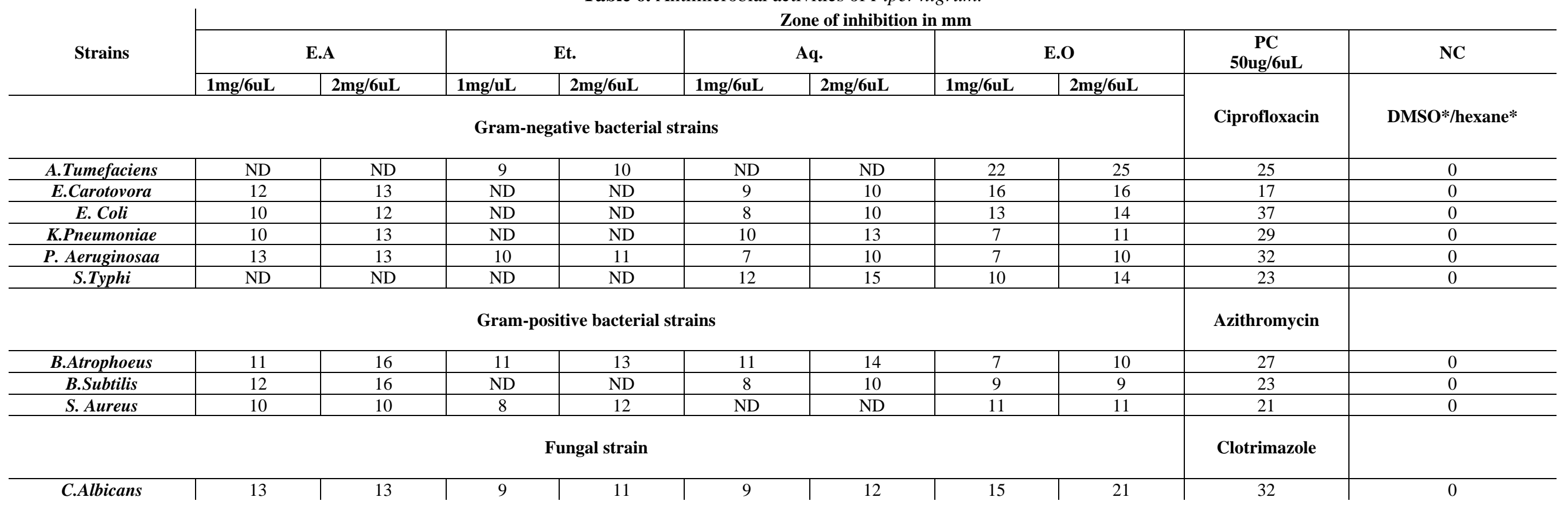




\subsection{Discussion.}

Medicinal herbs and spices contain a large number of bioactive compounds. Their isolation from plant material largely depends on the type of solvent used in the extraction procedure. In the present study, the aqueous extract showed less extractive yield as compared to ethyl acetate and ethanolic extracts; this may be due to the presence of a lesser amount of water-soluble components [26], while most of the phytochemicals being organic in nature were soluble in organic solvents. However, our results proposed that a higher extractive yield does not always account for higher biological activity. The experimental data obtained from antimicrobial activities of various extracts against pathogenic microbes demonstrated the higher potential of aqueous and essential oil extracts, despite their low extractive yields $(2.15 \%)$ and $(1.25 \%)$ respectively than ethanolic $(4.25 \%)$ and ethyl acetate $(4.45 \%)$ extracts. It can be hypothesized that bio-active components essentially account for biological activities, not the amount of extract obtained after extraction with a particular solvent. Moreover, the synergic effects of one compound may enhance or mask the other's activity, irrespective of the extractive yield.

The proximate analysis evaluated the nutritional profile of $P N$ fruits, indicating its carbohydrate-rich $(42.66 \%)$ constitution, thus supporting the high energy value of $P N$. The presence of dietary fibers makes it a valuable spice, and it is used in the treatment of obesity, gastrointestinal diseases, diabetes, and cancer [27]. The reported moisture content (11.4\%) was found in the optimum range (5-14\%) necessary for the maintenance of spices, which further aids to its nutritional worth [28].

The ash obtained was subjected to detail elemental analysis to get an idea about the presence of both toxic metals and micro or macronutrients. The AAS revealed that $\mathrm{Ca}$ $(30.400 \mathrm{mg} / \mathrm{L})$ and $\mathrm{Mg}(10.475 \mathrm{mg} / \mathrm{L})$ are present in the highest concentrations, which has been found to play important roles in the functioning of heart muscles, blood coagulation, maintenance of cell permeability [29], and in the prevention of heart diseases [30], respectively. The concentrations of $\mathrm{Cu}, \mathrm{Cr}$, and $\mathrm{Ni}$ in the present approach are analogous with previous results [31]. To explore the presence of biologically important secondary metabolites, a qualitative study was designed that revealed the presence of alkaloids, terpenoids, steroids, flavonoids, and glycosides in both organic and aqueous extracts, which are in accordance with the study of [32]. Conversely, tannins were detected in our study.

Phytochemical qualitative analysis is not a reliable technology and is only used for the apparent biological metabolites present in the extract. Therefore, we focused on a more reliable and precise GCMS technique to identify the studied plant oil's exact chemical constituents.

The GCMS analysis revealed that the essential oil of $P N$ is a complex mixture of various biologically active compounds, many of which are present in small amounts. We identified 24 volatile components in our sample. While recent studies by [14] showed the presence of 14 and 18 components in their plant samples collected from two different geographic areas [14]. The concentration of caryophyllene $(9.91 \%)$ was in the optimum range in the present study since it has been identified as a major component in literature [14]. Some of these chemical constituents like D-limonene, pinene, and caryophyllene, are reported for their strong chemopreventive, immunomodulatory, anti-inflammatory, antiatherosclerotic, antioxidant, local anesthetic, and antimicrobial activities. Alpha and beta-pinene are known to possess significant potential to inhibit some infectious microbes' cellular growth and capability [33, 34, 35, 36, 37]. Interestingly, approximately 250 volatile components have been identified in $P N$ oil from 
diverse geographical origins, demonstrating a diverse array of therapeutic potentials. [38, 39]. One of the limitations of our study is that we did not work with pure or isolated compounds from the tested extracts. However, based on the quantitative abundance of the constituents in the present study, it is plausible to assume that the observed antioxidant (Fig.1) and antimicrobial (Table 6) activities could be attributed to these compounds.

The in vitro system (phospholipids extract) has been used to characterize the antioxidant activity of a variety of synthetic and natural products [40, 41]. Our data (Fig.1) shows that $\mathrm{Fe}$ (II) caused a significant increase in TBARS production, and $P N$ inhibited lipid peroxidation at the highest tested concentrations. The antioxidant activity could be due to the presence of phenolic and flavonoids contents in the extract.

It is important to note that TBARS method has some limitations, such as the detection of products that are not derived from lipid peroxidation. Similarly, high temperature may cause the artefactual formation of lipid peroxidation products during color development. Data from our laboratory [42] has investigated and recently compared Ohkawa's colorimetric method with a high-performance liquid chromatographic (HPLC) analysis. We observed that there was no significant difference between the two methods. The color in homogenates by the TBA reaction method was directly proportional to the specific adduct of MDA-TBA (which can only be derived from lipid peroxidation) in the HPLC method. The presence of SDS in the color reaction medium protects the artefactual increase in TBARS formation. There is also considerable literature that used the TBARS method; for example, TBARS formation is dependent on free iron, i.e., iron chelators blunt TBARS formation, factors that release iron from proteins increase TBARS production (for instance, $\mathrm{pH}$ ) [43]. Consequently, although part of the observed TBARS production cannot be attributed to lipid peroxidation, a great proportion of the TBARS determined in our assay is derived from MDA (a product of unsaturated free fatty acid oxidation and decomposition).

The antimicrobial data suggested the effectiveness of aqueous extract over organic extracts, which may be attributed to the solubility of therapeutic components in water; hence we concluded that the presence of tannins in water extract probably explains its exhibition of better antimicrobial potential. Our findings are in strong contrast to [44], who reported the promising antimicrobial activities of ethanolic extract, while we did not observe remarkable activities of ethanolic extract. The true mechanism of antimicrobial activity is unknown, [45] but the well-known hypothesis about antimicrobial action involves the binding ability of phenolic compounds to membrane proteins, which cause partition in the lipid bilayer followed by increased fluidity as a result of the electron transport systems and cell wall destructruction occurred [46]. The fungicidal activity has been explained as the plants produce certain lytic enzymes that are responsible for the breakage of the fungal cell wall [47].

The antimicrobial activities of all the extracts were compared with the standard antibiotics. The essential oil and aqueous extracts showed considerable activities compared to the used antibiotics, suggesting a broad antimicrobial spectrum of $P N$.

\section{Conclusions}

We have proved from a diverse experimental study the rich nutritional aspects of $P N$, which serve as a useful source of important energy molecules. Being a common dietary spice, the investigation of basal concentration of various toxic metals was performed, and it can be concluded that the local variety of $P N$ does not contain any toxic metal in higher concentrations, i.e., above permissible levels, thus evaluating its safety index. The secondary metabolites and 
essential oil of the studied $P N$ showed significant potentials as antioxidant and antimicrobial agents. It can be hypothesized from the present study that local variety of $P N$ can be useful individually and/or in synergism with standard antibiotics to combat various pathogenic infectious diseases and may also be proved beneficial for the treatment of oxidative stressrelated pathologies situations. Furthermore, advanced research and detailed investigations are needed to isolate these compounds in pure form as they can be the potential lead sources for formulations of new antimicrobial therapeutic agents.

\section{Funding}

The financial support of HEC, Islamabad, Pakistan is highly appreciated.

\section{Acknowledgments}

This research has no acknowledgment.

\section{Conflicts of Interest}

The authors declare no conflict of interest.

\section{References}

1. Jamila, N.; Khan, N.; Bibi, A.; Haider, A.; Khan, S. N.; Atlas, A. Piper longum catkin extract mediated synthesis of $\mathrm{Ag}, \mathrm{Cu}$, and $\mathrm{Ni}$ nanoparticles and their applications as biological and environmental remediation agents. Arab. J. Chem. 2020, 8, 6425-6436. https://doi.org/10.1016/j.arabjc.2020.06.001

2. Yabalak, E.; Ibrahim, F.; Eliuz, E. A. E.; Everest, A.; Gizir, A. M. Evaluation of chemical composition, trace element content, antioxidant and antimicrobial activities of Verbascum pseudoholotrichum. Plant Biosyst., 2020, 1-10. https://doi.org/10.1080/11263504.2020.1852332

3. da Silva, L. E.; Confortin, C.; Swamy, M. K. Antibacterial and Antifungal Plant Metabolites from the Tropical Medicinal Plants. In Bioactive Natural Products for Pharmaceutical Applications. Springer, Cham.2021, 263-285. https://doi.org/10.1007/978-3-030-54027-2_7

4. Dodson, C.D.; Dyer, L.A.; Searcy, J.; Wright, Z.; Letourneau, D.K. Cenocladamide, a dihydropyridone alkaloid from Piper cenocladum. Phytochemistry 2000, 53, 51-54, https://doi.org/10.1016/S00319422(99)00446-X.

5. Takooree, H.; Aumeeruddy, M.Z.; Rengasamy, K.R.R.; Venugopala, K.N.; Jeewon, R.; Zengin, G.; Mahomoodally, M.F. A systematic review on black pepper (Piper nigrum L.): from folk uses to pharmacological applications. Crit Rev Food Sci Nutr 2019, 59, S210-s243, https://doi.org/10.1080/10408398.2019.1565489.

6. El Hamss, R.; Idaomar, M.; Alonso-Moraga, A.; Muñoz Serrano, A. Antimutagenic properties of bell and black peppers. Food and Chemical Toxicology 2003, 41, 41-47, https://doi.org/10.1016/S02786915(02)00216-8.

7. Dorman, H.J.; Deans, S.G. Antimicrobial agents from plants: antibacterial activity of plant volatile oils. $J$ Appl Microbiol 2000, 88, 308-316, https://doi.org/10.1046/j.1365-2672.2000.00969.x.

8. Gulcin, I. The antioxidant and radical scavenging activities of black pepper seeds. Int. J. Food Sci. Nutr 2005, 56, 491-499.

9. Joshi, D.R.; Shrestha, A.C.; Adhikari, N. A Review On Diversified Use Of The King Of Spices: Piper Nigrum (Black Pepper). International Journal Of Pharmaceutical Sciences And Research 2018, 9, 40894101, https://doi.org/10.13040/IJPSR.0975-8232.9(10).4089-01.

10. Favre, L.C.; Rolandelli, G.; Mshicileli, N.; Vhangani, L.N.; dos Santos Ferreira, C.; van Wyk, J.; Buera, M.d.P. Antioxidant and anti-glycation potential of green pepper (Piper nigrum): Optimization of $\beta$ cyclodextrin-based extraction by response surface methodology. Food Chemistry 2020, 316, https://doi.org/10.1016/j.foodchem.2020.126280.

11. Li, Y.-X.; Zhang, C.; Pan, S.; Chen, L.; Liu, M.; Yang, K.; Zeng, X.; Tian, J. Analysis of chemical components and biological activities of essential oils from black and white pepper (Piper nigrum L.) in five provinces of southern China. LWT 2020, 117, https://doi.org/10.1016/j.lwt.2019.108644.

12. Ravindran, P.N. Black Pepper: Piper nigrum. Series: Medicinal and Aromatic Plants - Industrial Profiles.Center for Medicinal Plants Research, Kerala, India, In Stock CRC Press, 2000. 
13. Ao, P.; Hu, S.; Zhao, A. [Essential oil analysis and trace element study of the roots of Piper nigrum L]. Zhongguo Zhong yao za zhi = Zhongguo zhongyao zazhi = China journal of Chinese materia medica 1998, 23, 42-43, 63.

14. Aziz, S.; Shamsun, N.; Abukawsar, M.D.; Sudhungshu, K.R. Comparative Studies on Physicochemical Properties and GC-MS Analysis of Essential Oil of the Two Varieties of the Black Pepper (Piper nigrum Linn.). Intl. J. Pharma. Phytopharmacol. Res 2012, 2, 67-70.

15. Majeed, M.; Badmeev, V.; Rajendran, R. Use of piperine as a bioavailability enhancer. 09/005,594. 1999.

16. Ali, M.; Alam, N.M.; Yeasmin, M.S.; Khan, A.M.; Sayeed, M.A. Antimicrobial screening of different extracts of Piper longum Linn. Res J Agri Biol Sci 2007, 3, 852-857.

17. Rajkumar, V.; Gunasekaran, C.; Dharmaraj, J.; Chinnaraj, P.; Paul, C.A.; Kanithachristy, I. Structural characterization of chitosan nanoparticle loaded with Piper nigrum essential oil for biological efficacy against the stored grain pest control. Pesticide Biochemistry and Physiology 2020, 166, https://doi.org/10.1016/j.pestbp.2020.104566.

18. A.O.A.C. Official methods of analysis. 15th ed., Association of official analytical chemists. Washington DC, USA, 1990.

19. Pearson, D. Chemical Analysis of Foods. 7th ed. Churchill, Livingstone, London, 1976.

20. Siddiqui, A.A.; Ali, M. Practical Pharmaceutical chemistry. CBS Publishers and Distributors, 1997.

21. Iyengar, M.A. Study of Crude Drugs Manipal Power. 8th edition, 1995.

22. Ogunwande, I.A.; Olawore, N.O. Volatile fractions from the leaf and flowers of African Marigold", Tageteserecta Linn. from Nig. J. Essent. Oil Res 2006, 18, 366-368.

23. Ohkawa, H.; Ohishi, N.; Yagi, K. Assay for lipid peroxides in animal tissues by thiobarbituric acid reaction. Analytical Biochemistry 1979, 95, 351-358, https://doi.org/10.1016/0003-2697(79)90738-3.

24. Fazal, H.; Ahmad, N.; Abbasi, B.; Abbas, N. Selected medicinal plants used in herbal industries; their toxicity against pathogenic microoraganisms. Pakistan Journal of Botany 2012, 44, 1103-1109.

25. Qureshi, M.N.; Siddique, M.; Kanwal, I.-U.-R.; Kanwal, F. Analytical Characterization of Fatty Acids Composition of Datura alba Seed Oil by Gas Chromatography Mass Spectrometry. Journal of the Chinese Chemical Society 2011, 58, 236-240, https://doi.org/10.1002/jccs.201190082.

26. Ujjaliya, N.; Vivek, P.; Remadevi, R. A comparative phytochemical screening of root and stem of Piper longum Linn. International Journal of Research in Ayurveda and Pharmacy 2012, 3, 67-69.

27. S Saldanha, L.G. Fiber in the diet of US children: results of national surveys. Pediatrics 1995, 96, 994-997.

28. Murphy, E.W.; Marsh, A.C.; Willis, B.W. Nutrient content of spices and herbs. J. Am. Dietet. Assoc 1978, 72, 174-176.

29. Heaney, R.P. Thinking straight about calcium. $N$ Engl J Med 1993, 328, 503-505, https://doi.org/10.1056/nejm199302183280710.

30. Scelig, M. Cardiovascular consequences of $\mathrm{Mg}$ deficiency and loss; pathogenesis, prevalence and manifestations. Am. J.Cardio 1989, 63, 1101-1102.

31. Kirmani, Z.; Mohiuddin, S.; Naz, F.; Naqvi, II.; Zahir, E. Determination of some toxic and essential trace metals in some medicinal and plants of Karachi city. J. Basic Appl. Sci 2011, 7, 89-95.

32. Nahak, D.G.; Sahu, R. Phytochemical evaluation and antioxidant activity of Piper cubeba and Piper nigrum. Journal of Applied Pharmaceutical Science 2011, 1, 153-157.

33. Ghelardini, C.; Galeotti, N.; Di Cesare Mannelli, L.; Mazzanti, G.; Bartolini, A. Local anaesthetic activity of beta-caryophyllene. Farmaco (Societa chimica italiana:1989) 2001, 56, 387-389, https://doi.org/10.1016/s0014-827x(01)01092-8.

34. da Silva, S.L.; Figueiredo, P.M.S.; Yano, T. Chemotherapeutic potential of the volatile oils from Zanthoxylum rhoifolium Lam leaves. European Journal of Pharmacology 2007, 576, 180-188, https://doi.org/10.1016/j.ejphar.2007.07.065.

35. Uedo, N.; Tatsuta, M.; Iishi, H.; Baba, M.; Sakai, N.; Yano, H.; Otani, T. Inhibition by d-limonene of gastric carcinogenesis induced by N-methyl-N'-nitro-N-nitrosoguanidine in Wistar rats. Cancer Letters 1999, 137, 131-136, https://doi.org/10.1016/S0304-3835(98)00340-1.

36. Matsuo, A.L.; Figueiredo, C.R.; Arruda, D.C.; Pereira, F.V.; Borin Scutti, J.A.; Massaoka, M.H.; Travassos, L.R.; Sartorelli, P.; Lago, J.H.G. $\alpha$-Pinene isolated from Schinus terebinthifolius Raddi (Anacardiaceae) induces apoptosis and confers antimetastatic protection in a melanoma model. Biochemical and Biophysical Research Communications 2011, 411, 449-454, https://doi.org/10.1016/j.bbrc.2011.06.176.

37. Filipowicz, N.; Kamiński, M.; Kurlenda, J.; Asztemborska, M.; Ochocka, J.R. Antibacterial and antifungal activity of juniper berry oil and its selected components. Phytotherapy research : PTR 2003, 17, 227-231, https://doi.org/10.1002/ptr.1110.

38. Menon, A.N.; Chacko, S.; Narayanan, C.S. Free and Glycosidically Bound Volatiles of Pepper (Piper Nigrum L.). Journal of Essential Oil Research 2001, 13, 166-169, https://doi.org/10.1080/10412905.2001.9699650.

39. Pruthi, J.S. Major Spices of India: Crop Management and PostHarvest Technology. Indian Council of Agriculture Research. New Delhi, xxii + 514. 1993.

40. Oboh, G.; Rocha, J.B. Hot Pepper (Capsicum spp.) protects brain from sodium nitroprusside- and quinolinic acid-induced oxidative stress in vitro. J Med Food 2008, 11, 349-355, https://doi.org/10.1089/jmf.2007.341. 
41. Sabir, S.M.; Rocha, J.B.T. Water-extractable phytochemicals from Phyllanthus niruri exhibit distinct in vitro antioxidant and in vivo hepatoprotective activity against paracetamol-induced liver damage in mice. Food Chemistry 2008, 111, 845-851, https://doi.org/10.1016/j.foodchem.2008.04.060.

42. Puntel, R.L.; Roos, D.H.; Grotto, D.; Garcia, S.C.; Nogueira, C.W.; Batista Teixeira Rocha, J. Antioxidant properties of Krebs cycle intermediates against malonate pro-oxidant activity in vitro: A comparative study using the colorimetric method and HPLC analysis to determine malondialdehyde in rat brain homogenates. Life Sciences 2007, 81, 51-62, https://doi.org/10.1016/j.lfs.2007.04.023.

43. Hassan, W.; Ibrahim, M.; Nogueira, C.W.; Braga, A.L.; Deobald, A.M.; Mohammadzai, I.U.; Rocha, J.B. Influence of $\mathrm{pH}$ on the reactivity of diphenyl ditelluride with thiols and antioxidant potential in rat brain. Chem Biol Interact 2009, 180, 47-53, https://doi.org/10.1016/j.cbi.2008.12.013.

44. Pundir, R.K.; Jain,P. Comparative studies on the antimicrobial activities of black pepper (Piper nigrum) and turmeric (curcuma longa) Extracts. Int. j. appl. biol. pharm 2010, 1, 492-501.

45. Lanciotti, R.; Gianotti, A.; Patrignani, F.; Belletti, N.; Guerzoni, M.E.; Gardini, F. Use of natural aroma compounds to improve shelf-life and safety of minimally processed fruits. Trends in Food Science \& Technology 2004, 15, 201-208, https://doi.org/10.1016/j.tifs.2003.10.004.

46. Nigussie, D.; Davey, G.; Legesse, B. A.; Fekadu, A.; Makonnen, E. Antibacterial activity of methanol extracts of the leaves of three medicinal plants against selected bacteria isolated from wounds of lymphoedema patients. BMC Comp. Med. Therap. 2021, 1, 1-10. https://doi.org/10.1186/s12906-02003183-0

47. Rubab, S.; Bahadur, S.; Hanif, U.; Durrani, A. I.; Sadiqa, A.; Shafique, S.; Iqbal, S. Phytochemical and antimicrobial investigation of methanolic extract/fraction of Ocimum basilicum L. Biocatal. Agric. Biotechnol., 2021. 31,101894. https://doi.org/10.1016/j.bcab.2020.101894 